\title{
THE INFLUENCE OF THE COVID-19 PANDEMIC ON MANAGEMENT ACTIONS AND THE FINANCIAL PERFORMANCE OF ENTERPRISES IN POLAND DURING THE FIRST HALF OF 2020
}

\begin{abstract}
The unexpected outbreak of the COVID-19 pandemic caused severe issues globally, with problems focused on health, social, and economic factors. Many economies experienced shocks to supply and demand. This article presents the findings of Statistics Poland's research on the experiences of enterprises and managerial activities undertaken during the COVID-19 pandemic, as well as the degree of changes in financial performance for the first half of 2020. The analyses have shown that approximately $90 \%$ of the enterprises surveyed in Poland in the first half of 2020 experienced a negative impact from the COVID-19 pandemic, while approximately $70 \%$ took management actions to mitigate the negative impacts. In addition, taking into account changes in financial performance, construction companies appear to be in the best situation, as their net financial results increased by approximately $44 \%$ compared to the first half of 2019. Companies in the processing industry appear to have been worst hit, as their net financial results decreased by as much as $40 \%$ compared to the same period in 2019 .
\end{abstract}

Keywords: COVID-19 pandemic, financial performance, business activity.

\section{INTRODUCTION}

At the beginning of 2020, the world was apparently on the threshold of another crisis, whose primary, though not only, cause was the SARS-CoV-2 coronavirus and the COVID19 illness it triggers. The pandemic has had severe negative consequences, not only in terms of health and society, but also economically. An attempt to reduce the number of illnesses by introducing social distancing had a destructive effect on public finances, enterprises and citizens. In view of the enormous importance of enterprises in the economy, the article undertakes the following research problems:

1. whether enterprises in Poland experienced negative effects from the COVID-19 pandemic in the first half of 2020 and took management actions to mitigate them,

2. what is the financial performance of enterprises in Poland in the first half of 2020 ?

The aim of the article is to present the results of analyses of Statistics Poland's data on the experiences of enterprises and management actions undertaken during the COVID-19 pandemic in the first half of 2020, as well as the degree of changes in the financial

\footnotetext{
${ }^{1}$ Sabina Rokita, PhD, Department of Finance, Banking and Accountancy, Rzeszow University of Technology, al. Powstańców Warszawy 12, 35-959 Rzeszów, Poland; e-mail: srokita@prz.edu.pl. ORCID: 0000-0002-2185-6399.
} 
performance of enterprises for the first half of 2020 compared to the same period the previous year.

\section{THE IMPACT OF THE COVID-19 PANDEMIC ON BUSINESS}

The rate of spread of the SARS-CoV-2 coronavirus as well as the incidence of COVID-19 has taken the whole world by surprise. Apparently, the first infection with the SARS-CoV-2 coronavirus occurred on November 17, 2019 in China (Rzeczpospolita, 2020), and at the end of June 2020 there were approximately 10 million infected people globally, and over 500,000 had died due to COVID-19 (polsatnews.pl, 2020). In many countries, the health service were overloaded, and attempts were made to stop the spread of the coronavirus, including introducing restrictions on movement in public places the operation of businesses, closing borders, and banning mass gatherings. The most important economic problems resulting from this include: increased costs to health care, an increase in public debt, a decrease in labor productivity, an increase in unemployment, a decrease in GDP, the upsetting of global value chains of goods and services, and a limitation of investments (Oldekop et al., 2020; Goodell, 2020; Craven et al., 2020).

The SARS-CoV-2 coronavirus initially attacked China, where as a result of illnesses and the introduction of restrictions aimed at suppressing infection outbreaks, the activities of companies, including manufacturing companies, were slowed down or even suspended. Delays caused by production downtime have further aggravated restrictions on international transport. Consequently, issues began to appear in those entities whose activities were to some extent dependent on supplies from China, and ergo, practically all over the world. Disruptions in global supply chains arose. In addition, the rate of spread of the SARS-CoV-2 coronavirus, its impact on practically every aspect of functioning, as well as great uncertainty, caused a change in existing consumer preferences. Economies experienced a shock to both supply and demand (McKibbin, Fernando, 2020).

However, the Covid-19 pandemic affects different sectors and actors in different ways and to varying degrees. Some businesses experience mostly negative consequences, others positive ones. Restrictions to movement affected, among others, a decline in the demand for hotel and restaurant services, which translated into a decrease in the demand for agricultural products. Aviation (especially airlines and airports, due to reduced passenger traffic), tourism and the service sector may suffer difficulties. Opportunities for development, in turn, appeared in the pharmaceutical industry, e.g. companies involved in the development of a vaccine for Covid-19, as well as the manufacture of respirators. Markets, in turn, experienced a siege at the beginning of the pandemic due to panic and forward buying. Companies operating in the field of information technology, conducting online sales or courier activities are experiencing a period of glory (Nicola et al., 2020; Craven et al., 2020).

Research shows, however, that the situation of enterprises is influenced not only by the industry and type of business, but also by their size - usually the smaller ones more suffer the negative effects of the crisis caused by the coronavirus and are more prone to bankruptcy (Bartik et al., 2020; Bartik et al., 2020a).

The numerous problems and challenges caused by the Covid-19 pandemic and the desire to survive in difficult times force a search for new ways of functioning, better and more efficient use of resources, as evidenced by, inter alia, the implementation in organizations of so-called imposed service innovations (e.g. delivery of parcels with the use of robots, 
virtual medical visits), which under normal operating conditions might not have a chance to exist because of adopted business strategies and a focus on stability and linear development (Heinonen, Strandvik, 2020), which can be considered a favorable aspect of its impact. Moreover, in a broader perspective, as Ch. Wyplosz notes, ways of responding to threats caused by the coronavirus reveal the true nature of governments and societies (Wyplosz, 2020).

Under the influence of these events, a huge uncertainty appeared in societies, related not only to the duration of the pandemic and the duration of restrictions, health concerns, the possibility of discovering a vaccine or an effective drug for COVID-19, but also concern for material existence, the possibility of maintaining employment or the scale of changes in economies. An analysis of the values of selected economic uncertainty indicators from the USA and UK (including VIX implied stock returns volatility, News Economic Policy Uncertainty, Twitter Economic Uncertainty, Firm Subjective Sales Uncertainty, Macro Forecaster disagreement, Model-Based Macro Uncertainty) from the first half of 2020 demonstrated that all of them indicate huge spikes in uncertainty in response to a pandemic, with most reaching their highest recorded levels. In addition, it was noted that the negative impact of the COVID-19 pandemic on the economy is surprisingly large (as evidenced in the USA and UK by, among others, a dozen or even several dozen percent increase in the number of unemployed individuals or claims for unemployment benefits, drops in production or GDP), to mortality caused by this illness (which during the study period was at a much lower level than, for example, during the Spanish Flu). The authors of the study see the reasons for this in the unusual scale and nature of COVID-19 (Altig et al., 2020). However, this uncertainty has a huge impact on the structure and size of demand.

\section{RESEARCH SUBJECT AND METHODOLOGY}

The subject of the research was the experiences of enterprises in Poland and management actions undertaken during the COVID-19 pandemic in the first half of 2020, as well as financial performance for the first half of 2019 and 2020. The analysis examined data from Statistics Poland on the economic situation and financial performance of non-financial enterprises for the first half of 2019 and 2020.

Research on the business tendency survey allows for the assessment of the situation of the enterprise sector and its individual departments, based on the opinions of entrepreneurs regarding the current and future conditions of their functioning, based on their impressions, and not on data contained in accounting systems (GUS, 2018). The research is conducted by the Statistics Poland on a monthly basis (from the 1st to the 10th day of the month), using surveys that, from April 2020, also contain questions about the impact of the SARS-CoV-2 coronavirus on the economic situation. The research is carried out among entities conducting business activity classified as (sections according to NACE REV. 2) (GUS, 2020a-2020f):

- manufacturing (section C) - the sample includes 3,500 enterprises,

- construction (section F) - the sample includes 3,999 enterprises,

- trade (section G, including wholesale and retail trade) - the sample includes 7,797 enterprises,

- services - the sample covers 5,000 enterprises, including:

- Transportation and storage (section H),

- Accommodation and food service activities (section I), 
- Information and communication (section J not including cultural institutions with a legal personality),

- Financial and insurance activities (section K),

- Real estate activities (section L),

- Professional, scientific and technical activities (section $\mathrm{M}$ ),

- Administrative and support service activities (section N),

- Education (section P not including universities),

- Human health and social work activities (section Q not including health maintenance organizations),

- Arts, entertainment and recreation (section $\mathrm{R}$ not including cultural institutions with legal personality),

- Other service activities (section S not including division 94 - activities of membership organizations).

Statistics Poland conducts quarterly research on revenues, costs and financial results among enterprises keeping account books and employing at least 10 people (GUS, 2019). The article uses the results of surveys of enterprises operating in the same sections according to NACE REV. 2, which were indicated in the survey of the economic situation, with the exception of section K Financial and insurance activities. The number of enterprises covered by the financial performance survey is shown in tables 5-8.

The research method utilized in this article was desk research - secondary data analysis using the aforementioned Statistics Poland databases. Comparative analysis was conducted with respect to financial data, perceived negative effects of the COVID-19 pandemic and management measures to counteract these negative effects in enterprises in Poland.

\section{EXPERIENCE AND MANAGEMENT ACTIONS OF ENTERPRISES IN POLAND DURING THE COVID-19 PANDEMIC}

In Poland, initial preparations for the emergence of SARS-CoV-2 coronavirus infections were undertaken at the turn of January and February 2020, and from March 2020 a number of restrictions have been introduced for movement in a public place, organizing mass gatherings, and the way institutions function and conduct business activities (e.g. limiting the number of people who may simultaneously be inside stores or service points). The uncertainty connected with the emergence of a new infectious disease and the implemented restrictions had already affected enterprises in the first half of 2020.

The results of the value of the general business climate indicator from January to June 2020 are presented in Table 1.

The general business climate indicator is a composite measure presenting a synthetic assessment of the current and forecasted activity of enterprises including, based on their general condition, business barriers, financial situation, employment, demand for finished products, and goods or services (GUS, 2020). As demonstrated by an analysis of the data contained in Table 1, the values of this indicator significantly deteriorated in Q2 2020, i.e. they showed a significant deterioration in the sentiment of entrepreneurs after the introduction of restrictions related to the prevention of the spread of the SARS-CoV-2 coronavirus. Pessimistic moods prevailed among all entities, i.e. those operating in manufacturing, construction, trade, and services. The general business climate indicator in manufacturing in April 2020 was minus 44.2, in construction minus 47.1, in wholesale trade 
minus 39.8, in retail minus 48.3, in services (e.g. accommodation and catering) as low as minus 70, and as emphasized by Statistics Poland, the economic situation in April 2020 was assessed as "the worst in all the presented areas of the economy since the beginning of the survey (GUS, 2020g)”.

Table 1. General business climate indicator in the months of January-June 2020 (possible maximum values: from -100 to +100 )

\begin{tabular}{|l|c|c|c|c|c|c|}
\hline $\begin{array}{l}\text { General business climate indicator } \\
\text { (non-seasonally adjusted indicator) } \\
\text { in selected areas of activity: }\end{array}$ & $\begin{array}{c}\text { January } \\
\mathbf{2 0 2 0}\end{array}$ & $\begin{array}{c}\text { February } \\
\mathbf{2 0 2 0}\end{array}$ & $\begin{array}{c}\text { March } \\
\mathbf{2 0 2 0}\end{array}$ & $\begin{array}{c}\text { April } \\
\mathbf{2 0 2 0}\end{array}$ & $\begin{array}{c}\text { May } \\
\mathbf{2 0 2 0}\end{array}$ & $\begin{array}{c}\text { June } \\
\mathbf{2 0 2 0}\end{array}$ \\
\hline manufacturing & 3.2 & 1.6 & -1.1 & -44.2 & -34.9 & -19.9 \\
\hline construction & -0.7 & 0.1 & -1.9 & -47.1 & -38.8 & -25.9 \\
\hline wholesale trade & 4.0 & 4.5 & 0.4 & -39.8 & -33.3 & -16.5 \\
\hline $\begin{array}{l}\text { retail trade, including the repair of } \\
\text { motor vehicles }\end{array}$ & -0.3 & -0.8 & -3.1 & -49.5 & -43.4 & -25.1 \\
\hline transportation and storage & -0.5 & 0.1 & -5.8 & -48.3 & -39.4 & -20.4 \\
\hline $\begin{array}{l}\text { accommodation and food service } \\
\text { activities }\end{array}$ & -0.5 & -5.6 & -9.1 & -70.0 & -60.4 & -34.0 \\
\hline information and communication & 19.7 & 19.0 & 16.8 & -19.4 & -12.0 & -4.3 \\
\hline real estate market services & 3.5 & 8.8 & 6.4 & -29.9 & -25.9 & -9.7 \\
\hline
\end{tabular}

Source: personal study based on Statistics Poland's data (GUS 2020a-2020f).

The moods of enterprises improved in May and June 2020, possibly due to the gradual easing of the restrictions introduced at the turn of March and April 2020, and the introduction of financial support programs aimed at mitigating the negative effects of the pandemic, which is visible in the successively increasing values of the general climate indicators of the economic situation.

In each of the months from March to June 2020, more than $90 \%$ of enterprises have experienced the negative effects of the coronavirus pandemic, albeit to a different extent: insignificant, serious, or even threatening their stability. In each of the analyzed areas of activity, entities indicating a threat to their stability were generally from a few to a dozen or so percent, and these values were the highest in April 2020. Moreover, in April 2020 it was at that moment that the largest number of enterprises operating in retail indicated a threat to stability, as much as $22.90 \%$. Detailed results of Statistics Poland's research in this area are presented in Table 2.

In the face of new challenges, enterprises proved to be very active in taking management actions aimed at counteracting the negative effects caused by the SARS-CoV-2 coronavirus pandemic (Table 3).

As shown in Table 3, manufacturing companies were the outright leaders in this regard, because in the period of March-June 2020 as many as $33.00 \%$ to $41.10 \%$ of them took actions strongly affecting functioning, in order to mitigate the negative effects of the pandemic, while slightly affecting from $51.10 \%$ to $56.00 \%$. Slightly less active in this respect were enterprises conducting a wholesale, retail or services trade - decisions strongly influencing the activity were made by $25.00 \%$ to $39.30 \%$ of the surveyed entities, while slightly influencing ones were implemented by $48.30 \%$ to $58.90 \%$ of them. On the other 
hand, the fewest of the surveyed enterprises indicated that measures were taken to mitigate the negative effects of the pandemic strongly affecting construction activity, i.e. from $15.80 \%$ to $24.20 \%$. Actions slightly affecting functioning were introduced by $55.70 \%$ to $62.50 \%$ of entities, while no special activities were undertaken in this regard for $19.60 \%$ to $28.50 \%$ of them.

Table 2. The "coronavirus" pandemic and its impact on a company's operations in the period March-June 2020.

\begin{tabular}{|c|c|c|c|c|c|}
\hline \multicolumn{2}{|c|}{$\begin{array}{l}\text { In connection with the outbreak of the } \\
\text { "coronavirus" pandemic and its } \\
\text { consequences, have you possibly experienced } \\
\text { negative consequences in your business? }\end{array}$} & \multirow{2}{*}{$\begin{array}{c}\begin{array}{c}\text { March } \\
\mathbf{2 0 2 0}\end{array} \\
65.30 \% \\
\end{array}$} & \multirow{2}{*}{$\begin{array}{l}\text { April } \\
\mathbf{2 0 2 0} \\
35.50 \%\end{array}$} & \multirow{2}{*}{$\begin{array}{l}\text { May } \\
\mathbf{2 0 2 0} \\
41.10 \% \\
\end{array}$} & \multirow{2}{*}{$\begin{array}{l}\text { June } \\
\mathbf{2 0 2 0} \\
51.00 \% \\
\end{array}$} \\
\hline \multirow{4}{*}{ Manufacturing } & \begin{tabular}{|l|} 
slight \\
\end{tabular} & & & & \\
\hline & serious & $29.40 \%$ & $47.20 \%$ & $43.50 \%$ & $37.20 \%$ \\
\hline & $\begin{array}{l}\text { threatening the stability of the } \\
\text { company }\end{array}$ & $5.30 \%$ & $13.00 \%$ & $9.90 \%$ & $5.70 \%$ \\
\hline & no negative effects & - & $4.30 \%$ & $5.50 \%$ & $6.10 \%$ \\
\hline \multirow{4}{*}{ Construction } & slight & $63.70 \%$ & $42.30 \%$ & $47.00 \%$ & $52.50 \%$ \\
\hline & serious & $28.40 \%$ & $41.30 \%$ & $35.30 \%$ & $28.80 \%$ \\
\hline & $\begin{array}{l}\text { threatening the stability of the } \\
\text { company }\end{array}$ & $7.90 \%$ & $12.90 \%$ & $11.60 \%$ & $10.30 \%$ \\
\hline & no negative effects & - & $3.50 \%$ & $6.10 \%$ & $8.40 \%$ \\
\hline \multirow{4}{*}{$\begin{array}{c}\text { Wholesale } \\
\text { trade }\end{array}$} & slight & $62.60 \%$ & $40.10 \%$ & $47.30 \%$ & $52.20 \%$ \\
\hline & serious & $28.30 \%$ & $39.30 \%$ & $39.20 \%$ & $33.40 \%$ \\
\hline & $\begin{array}{l}\text { threatening the stability of the } \\
\text { company }\end{array}$ & $9.10 \%$ & $14.30 \%$ & $7.10 \%$ & $6.60 \%$ \\
\hline & no negative effects & - & $6.30 \%$ & $6.40 \%$ & $7.80 \%$ \\
\hline \multirow{4}{*}{ Retail trade } & slight & $48.20 \%$ & $28.20 \%$ & $32.40 \%$ & $42.80 \%$ \\
\hline & serious & $35.30 \%$ & $45.90 \%$ & $49.80 \%$ & $41.60 \%$ \\
\hline & $\begin{array}{l}\text { threatening the stability of the } \\
\text { company }\end{array}$ & $16.50 \%$ & $22.90 \%$ & $15.50 \%$ & $9.60 \%$ \\
\hline & no negative effects & - & $3.00 \%$ & $2.30 \%$ & $6.00 \%$ \\
\hline \multirow{4}{*}{ Services } & slight & $56.00 \%$ & $43.00 \%$ & $37.50 \%$ & $49.20 \%$ \\
\hline & serious & $33.90 \%$ & $37.80 \%$ & $45.30 \%$ & $32.70 \%$ \\
\hline & $\begin{array}{l}\text { threatening the stability of the } \\
\text { company }\end{array}$ & $10.10 \%$ & $15.60 \%$ & $13.10 \%$ & $12.10 \%$ \\
\hline & no negative effects & - & $3.60 \%$ & $4.10 \%$ & $6.00 \%$ \\
\hline
\end{tabular}

Source: personal study based on Statistics Poland's data (GUS, 2020h-2020j). 
Table 3. Management actions taken aimed at reducing the negative effects of the "coronavirus" pandemic for the company in the period March-June 2020

\begin{tabular}{|c|c|c|c|c|c|}
\hline \multicolumn{2}{|c|}{$\begin{array}{l}\text { In connection with the outbreak of the } \\
\text { "coronavirus" pandemic, have you implemented } \\
\text { any measures to reduce its negative effects on the } \\
\text { company? }\end{array}$} & \multirow{2}{*}{$\begin{array}{c}\text { March } \\
\mathbf{2 0 2 0} \\
56 \% \\
\end{array}$} & \multirow{2}{*}{$\begin{array}{c}\text { April } \\
\mathbf{2 0 2 0} \\
51.20 \% \\
\end{array}$} & \multirow{2}{*}{$\begin{array}{l}\text { May } \\
\mathbf{2 0 2 0}\end{array}$} & \multirow{2}{*}{$\begin{array}{l}\text { June } \\
\mathbf{2 0 2 0} \\
55.40 \% \\
\end{array}$} \\
\hline \multirow{3}{*}{ Manufacturing } & yes, slightly affecting the business & & & & \\
\hline & yes, strongly influencing & $33 \%$ & $39.60 \%$ & $41.10 \%$ & $35 \%$ \\
\hline & we did not take any special action & $11 \%$ & $9.20 \%$ & $7.80 \%$ & $9.60 \%$ \\
\hline \multirow{3}{*}{ Construction } & yes, slightly affecting the business & $55.70 \%$ & $55.80 \%$ & $62.50 \%$ & $57 \%$ \\
\hline & yes, strongly influencing & $15.80 \%$ & $24.20 \%$ & $17.90 \%$ & $21.30 \%$ \\
\hline & we did not take any special action & $28.50 \%$ & $20 \%$ & $19.60 \%$ & $21.70 \%$ \\
\hline \multirow{3}{*}{$\begin{array}{c}\text { Wholesale } \\
\text { trade }\end{array}$} & yes, slightly affecting the business & $52.80 \%$ & $53.20 \%$ & $52.30 \%$ & $58.90 \%$ \\
\hline & yes, strongly influencing & $25.60 \%$ & $28.90 \%$ & $31.60 \%$ & $25 \%$ \\
\hline & we did not take any special action & $21.60 \%$ & $17.90 \%$ & $16.10 \%$ & $16.10 \%$ \\
\hline \multirow{3}{*}{ Retail trade } & yes, slightly affecting the business & $52.70 \%$ & $48.30 \%$ & $52.30 \%$ & $50.80 \%$ \\
\hline & yes, strongly influencing & $28.90 \%$ & $39.30 \%$ & $38.20 \%$ & $37.70 \%$ \\
\hline & we did not take any special action & $18.40 \%$ & $12.40 \%$ & $9.50 \%$ & $11.50 \%$ \\
\hline \multirow{3}{*}{ Services } & yes, slightly affecting the business & $52.40 \%$ & $50.40 \%$ & $50.20 \%$ & $54.90 \%$ \\
\hline & yes, strongly influencing & $27.30 \%$ & $33.50 \%$ & $35 \%$ & $30.30 \%$ \\
\hline & we did not take any special action & $20.30 \%$ & $16.10 \%$ & $14.80 \%$ & $14.80 \%$ \\
\hline
\end{tabular}

Source: Personal study based on Statistics Poland's data (GUS, 2020h-2020j).

Unfortunately, the issue of mitigating the negative impact of the SARS-CoV-2 coronavirus on operations has not been included in more detail in the Statistics Poland's survey on the economic situation; hence it is not possible to precisely analyze specific strategies or methods undertaken by enterprises in this area (GUS, 2020). Nevertheless, undoubtedly one of the decisions taken by management that almost all enterprises had to face were those related to work, starting with the introduction of various measures to protect employees against infection, such as protective masks, gloves, disinfectants, to changes in the forms of work (e.g. introducing telework), shortening working hours, changes to working hour systems, and even up to the dismissal of employees.

The research of Statistics Poland demonstrated (Table 4) that in the period from March to June 2020, the percentage of employees working remotely and/or in similar forms varied between $24.10 \%$ and $46.20 \%$ in enterprises operating in wholesale trade and services. In the processing industry, construction and retail trade, from $5.50 \%$ to $17.00 \%$ of employees worked remotely or in similar forms. It can be noted, however, that in all the surveyed areas of enterprise activity, the percentage of people working remotely decreased with the incremental easing of restrictions, and thus the fewest people worked remotely in June 2020. 
Table 4. Forms of work in companies during the "coronavirus" pandemic in the period March-June 2020

\begin{tabular}{|c|c|c|c|c|c|}
\hline \multicolumn{2}{|c|}{$\begin{array}{l}\text { Estimated percentage of the company's employees } \\
\text { (regardless of the type of contract: employment, civil } \\
\text { law, self-employed workers, interns, agents, etc.) } \\
\text { covered by each of the following situations: }\end{array}$} & \multirow{2}{*}{$\begin{array}{c}\begin{array}{c}\text { March } \\
\mathbf{2 0 2 0}\end{array} \\
15 \%\end{array}$} & \multirow{2}{*}{$\begin{array}{c}\text { April } \\
\mathbf{2 0 2 0} \\
16.70 \%\end{array}$} & \multirow{2}{*}{$\begin{array}{l}\text { May } \\
\mathbf{2 0 2 0} \\
15.30 \% \\
\end{array}$} & \multirow{2}{*}{$\begin{array}{r}\text { June } \\
\mathbf{2 0 2 0} \\
10.50 \% \\
\end{array}$} \\
\hline \multirow{3}{*}{ Manufacturing } & telework and similar forms of work & & & & \\
\hline & $\begin{array}{l}\text { unplanned absences due to holidays, } \\
\text { care of children or family members, etc. }\end{array}$ & $10.80 \%$ & $10.90 \%$ & $7.50 \%$ & $6.10 \%$ \\
\hline & $\begin{array}{l}\text { lack of employees due to quarantine or } \\
\text { other restrictions }\end{array}$ & $3.20 \%$ & $2.90 \%$ & $2.80 \%$ & $1.60 \%$ \\
\hline \multirow{3}{*}{ Construction } & telework and similar forms of work & $14.50 \%$ & $11.90 \%$ & $12.70 \%$ & $5.50 \%$ \\
\hline & $\begin{array}{l}\text { unplanned absences due to holidays, } \\
\text { care of children or family members, etc. }\end{array}$ & $11.10 \%$ & $11.60 \%$ & $7.20 \%$ & $5.90 \%$ \\
\hline & $\begin{array}{l}\text { lack of employees due to quarantine or } \\
\text { other restrictions }\end{array}$ & $7.60 \%$ & $5 \%$ & $4.70 \%$ & $2.90 \%$ \\
\hline \multirow{3}{*}{$\begin{array}{l}\text { Wholesale } \\
\text { trade }\end{array}$} & telework and similar forms of work & $33.60 \%$ & $34.50 \%$ & $30.40 \%$ & $24.10 \%$ \\
\hline & $\begin{array}{l}\text { unplanned absences due to holidays, } \\
\text { care of children or family members, etc. }\end{array}$ & $13 \%$ & $9.60 \%$ & $7.80 \%$ & $6.80 \%$ \\
\hline & $\begin{array}{l}\text { lack of employees due to quarantine or } \\
\text { other restrictions }\end{array}$ & $3.50 \%$ & $3.10 \%$ & $1.80 \%$ & $0.70 \%$ \\
\hline \multirow{3}{*}{ Retail trade } & telework and similar forms of work & $17 \%$ & $16 \%$ & $14.50 \%$ & $11.50 \%$ \\
\hline & $\begin{array}{l}\text { unplanned absences due to holidays, } \\
\text { care of children or family members, etc. }\end{array}$ & $15.30 \%$ & $13 \%$ & $7.90 \%$ & $7.70 \%$ \\
\hline & $\begin{array}{l}\text { lack of employees due to quarantine or } \\
\text { other restrictions }\end{array}$ & $8.20 \%$ & $7.70 \%$ & $4.20 \%$ & $2.30 \%$ \\
\hline \multirow{3}{*}{ Services } & telework and similar forms of work & $44.40 \%$ & $46.20 \%$ & $40.20 \%$ & $35.40 \%$ \\
\hline & $\begin{array}{l}\text { unplanned absences due to holidays, } \\
\text { care of children or family members, etc. }\end{array}$ & $12.40 \%$ & $9.60 \%$ & $7.80 \%$ & $6.90 \%$ \\
\hline & $\begin{array}{l}\text { lack of employees due to quarantine or } \\
\text { other restrictions }\end{array}$ & $4 \%$ & $4.40 \%$ & $2.90 \%$ & $1.40 \%$ \\
\hline
\end{tabular}

Source: personal study based on Statistics Poland's data (GUS, 2020h-2020j).

The percentage of employees on unplanned leave, caring for children or dependants (from $5.90 \%$ to $15.30 \%$ ), as well as absent from work because of quarantine or other restrictions (from $0.70 \%$ to $8.20 \%$ ) was at a similar level in all the surveyed companies, regardless of the type of business. In the case of employees' absence, the same correlation can be noticed as in the case of telework, i.e. the percentage of people absent from work for various reasons decreased with the incremental easing of restrictions.

\section{FINANCIAL PERFORMANCE OF ENTERPRISES IN POLAND IN THE FIRST HALF OF 2020}

The existing market conditions, in which economic entities had to function, to a varying degree influenced their condition, including their financial situation. Tables 5-8 present the 
financial performance of enterprises operating in the field of manufacturing, construction, wholesale and retail trade and services in the first half of 2020.

Table 5. Financial performance of enterprises operating in the field of construction for the first half of 2020

\begin{tabular}{|l|c|c|c|}
\hline \multirow{2}{*}{ Items } & \multicolumn{3}{c|}{ Construction } \\
\cline { 2 - 4 } & $\begin{array}{c}\text { January-June } \\
\mathbf{2 0 1 9}\end{array}$ & $\begin{array}{c}\text { January-June } \\
\mathbf{2 0 2 0}\end{array}$ & $\mathbf{2 0 2 0 / 2 0 1 9}$ \\
\hline Enterprises covered by the study & 1139 & 1160 & $101.84 \%$ \\
\hline $\begin{array}{l}\text { Revenue from overall activity } \\
\text { (total revenues) }\end{array}$ & $50835404000 \mathrm{zł}$ & $51898720000 \mathrm{zł}$ & $102.09 \%$ \\
\hline $\begin{array}{l}\text { Tax deductible costs from overall activity } \\
\text { (total costs) }\end{array}$ & $49025277000 \mathrm{zł}$ & $49380353000 \mathrm{zł}$ & $100.72 \%$ \\
\hline $\begin{array}{l}\text { Financial result from the sale of products, } \\
\text { goods and materials }\end{array}$ & $1253762000 \mathrm{zł}$ & $2092600000 \mathrm{zł}$ & $166.91 \%$ \\
\hline Gross financial result & $1810127000 \mathrm{zł}$ & $2518367000 \mathrm{zł}$ & $139.13 \%$ \\
\hline Gross profit & $2679509000 \mathrm{zł}$ & $3356848000 \mathrm{zł}$ & $125.28 \%$ \\
\hline Gross loss & $869382000 \mathrm{zł}$ & $838481000 \mathrm{zł}$ & $96.45 \%$ \\
\hline Net financial result & $1454817000 \mathrm{zł}$ & $2091270000 \mathrm{zł}$ & $143.75 \%$ \\
\hline Net profit & $2345245000 \mathrm{zł}$ & $2937902000 \mathrm{zl}$ & $125.27 \%$ \\
\hline Net loss & $890428000 \mathrm{zł}$ & $846632000 \mathrm{zl}$ & $95.08 \%$ \\
\hline Share of total costs in total revenues & $96.44 \%$ & $95.15 \%$ & $98.66 \%$ \\
\hline
\end{tabular}

Source: personal study based on Statistics Poland's data (Local Data Bank).

Table 6. Financial performance of enterprises operating in the field of wholesale and retail trade for the first half of 2020

\begin{tabular}{|l|c|c|c|}
\hline \multirow{2}{*}{\multicolumn{1}{|c|}{ Items }} & \multicolumn{3}{c|}{ Wholesale and retail trade } \\
\cline { 2 - 4 } & $\begin{array}{c}\text { January-June } \\
\mathbf{2 0 1 9}\end{array}$ & $\begin{array}{c}\text { January-June } \\
\mathbf{2 0 2 0}\end{array}$ & $\mathbf{2 0 2 0 / 2 0 1 9}$ \\
\hline Enterprises covered by the study & 3232 & 3268 & $101.11 \%$ \\
\hline $\begin{array}{l}\text { Revenue from overall activity } \\
\text { total revenues) }\end{array}$ & $483590933000 \mathrm{zł}$ & $464634868000 \mathrm{zł}$ & $96.08 \%$ \\
\hline $\begin{array}{l}\text { Tax deductible costs from overall activity } \\
\text { (total costs) }\end{array}$ & $471542633000 \mathrm{zł}$ & $453940764000 \mathrm{zł}$ & $96.27 \%$ \\
\hline $\begin{array}{l}\text { Financial result from the sale of products, } \\
\text { goods and materials }\end{array}$ & $13093288000 \mathrm{zł}$ & $12158835000 \mathrm{zł}$ & $92.86 \%$ \\
\hline Gross financial result & $12048300000 \mathrm{zł}$ & $10694104000 \mathrm{zł}$ & $88.76 \%$ \\
\hline Gross profit & $15115962000 \mathrm{zł}$ & $15767186000 \mathrm{zł}$ & $104.31 \%$ \\
\hline Gross loss & $3067662000 \mathrm{zł}$ & $5073082000 \mathrm{zł}$ & $165.37 \%$ \\
\hline Net financial result & $9713663000 \mathrm{zł}$ & $8516709000 \mathrm{zł}$ & $87.68 \%$ \\
\hline Net profit & $12828664000 \mathrm{zł}$ & $13617064000 \mathrm{zł}$ & $106.15 \%$ \\
\hline Net loss & $3115001000 \mathrm{zł}$ & $5100355000 \mathrm{zł}$ & $163.74 \%$ \\
\hline Share of total costs in total revenues & $97.51 \%$ & $97.70 \%$ & $100.19 \%$ \\
\hline
\end{tabular}

Source: personal study based on Statistics Poland's data (Local Data Bank). 
Among the analyzed areas of the economy, only enterprises operating in the construction industry generated net financial results in the first half of 2020 higher by $43.75 \%$ than in the corresponding period of the previous year, with net profits increasing by $25.27 \%$, while losses decreased by $4.92 \%$. The achieved revenues were higher by $2.09 \%$ than in 2019 , and the costs incurred only increased by $0.72 \%$, which is reflected in the share of the total cost level in total revenues, which in the first half of 2019 was $96.44 \%$, and in 2020 decreased to $95.15 \%$.

The smallest decrease in net financial results was recorded by wholesale and retail companies, which were $12.32 \%$ lower in the first half of 2020 than in 2019 , including $6.15 \%$ higher net profits; but losses increased by as much as $63.74 \%$. Compared to the same period of the previous year, revenues and costs decreased to a similar extent, i.e. by approximately $4 \%$, while revenues decreased by $0.19 \%$ more than costs. For this reason, the share of costs in revenues in the first half of 2019 was $97.51 \%$, while in 2020 it was $97.70 \%$.

Table 7. Financial performance of enterprises operating in the field of services for the first half of 2020

\begin{tabular}{|l|c|c|c|}
\hline \multirow{2}{*}{\multicolumn{1}{|c|}{ Items }} & \multicolumn{3}{c|}{ Services } \\
\cline { 2 - 4 } & $\begin{array}{c}\text { January-June } \\
\mathbf{2 0 1 9}\end{array}$ & $\begin{array}{c}\text { January-June } \\
\mathbf{2 0 2 0}\end{array}$ & $\mathbf{2 0 2 0 / 2 0 1 9}$ \\
\hline Enterprises covered by the study & 4635 & 4779 & $103.11 \%$ \\
\hline $\begin{array}{l}\text { Revenue from overall activity } \\
\text { (total revenues) }\end{array}$ & $223340634000 \mathrm{zł}$ & $220309964000 \mathrm{zł}$ & $98.64 \%$ \\
\hline $\begin{array}{l}\text { Tax deductible costs from overall activity } \\
\text { (total costs) }\end{array}$ & $210154280000 \mathrm{zł}$ & $210577089000 \mathrm{zł}$ & $100.20 \%$ \\
\hline $\begin{array}{l}\text { Financial result from the sale of products, } \\
\text { goods and materials }\end{array}$ & $9841168000 \mathrm{zł}$ & $8115915000 \mathrm{zł}$ & $82.47 \%$ \\
\hline Gross financial result & $13186354000 \mathrm{zł}$ & $9732875000 \mathrm{zł}$ & $73.81 \%$ \\
\hline Gross profit & $16832595000 \mathrm{zł}$ & $16988407000 \mathrm{zł}$ & $100.93 \%$ \\
\hline Gross loss & $3646241000 \mathrm{zł}$ & $7255532000 \mathrm{zł}$ & $198.99 \%$ \\
\hline Net financial result & $10660817000 \mathrm{zł}$ & $7317718000 \mathrm{zł}$ & $68.64 \%$ \\
\hline Net profit & $14495274000 \mathrm{zł}$ & $14603428000 \mathrm{zł}$ & $100.75 \%$ \\
\hline Net loss & $3834457000 \mathrm{zł}$ & $7285710000 \mathrm{zł}$ & $190.01 \%$ \\
\hline Share of total costs in total revenues & $94.10 \%$ & $95.58 \%$ & $101.58 \%$ \\
\hline
\end{tabular}

Source: personal study based on Statistics Poland's data (Local Data Bank).

Service enterprises in the first half of 2020 achieved financial results at a level of $68.64 \%$ of those from the first half of 2019 , so the decrease amounted to $31.36 \%$, with the value of net profits increasing by $0.75 \%$; while losses increased by as much as $90.01 \%$. Revenues decreased by $1.36 \%$ and costs increased by $0.20 \%$. In the period January-June 2019 , the share of costs in revenues was $94.10 \%$; while in the period January-June 2020, $95.58 \%$. 
Table 8. Financial performance of enterprises operating in the field of manufacturing for the first half of 2020

\begin{tabular}{|l|c|c|c|}
\hline \multirow{2}{*}{ Items } & \multicolumn{3}{c|}{ Manufacturing } \\
\cline { 2 - 4 } & $\begin{array}{c}\text { January-June } \\
\mathbf{2 0 1 9}\end{array}$ & $\begin{array}{c}\text { January-June } \\
\mathbf{2 0 2 0}\end{array}$ & $\mathbf{2 0 2 0 / 2 0 1 9}$ \\
\hline Enterprises covered by the study & 6890 & 6901 & $100.16 \%$ \\
\hline $\begin{array}{l}\text { Revenue from overall activity } \\
\text { (total revenues) }\end{array}$ & $647463670000 \mathrm{zł}$ & $590377298000 \mathrm{zł}$ & $91.18 \%$ \\
\hline $\begin{array}{l}\text { Tax deductible costs from the overall } \\
\text { activity (total costs) }\end{array}$ & $610638241000 \mathrm{zł}$ & $567175868000 \mathrm{zł}$ & $92.88 \%$ \\
\hline $\begin{array}{l}\text { Financial result from the sale of products, } \\
\text { goods and materials }\end{array}$ & $35086651000 \mathrm{zł}$ & $25812414000 \mathrm{zł}$ & $73.57 \%$ \\
\hline Gross financial result & $36825429000 \mathrm{zł}$ & $23201430000 \mathrm{zł}$ & $63.00 \%$ \\
\hline Gross profit & $41218329000 \mathrm{zł}$ & $35484070000 \mathrm{zł}$ & $86.09 \%$ \\
\hline Gross loss & $4392900000 \mathrm{zł}$ & $12282640000 \mathrm{zł}$ & $279.60 \%$ \\
\hline Net financial result & $31225372000 \mathrm{zł}$ & $19036764000 \mathrm{zł}$ & $60.97 \%$ \\
\hline Net profit & $35690174000 \mathrm{zł}$ & $30827745000 \mathrm{zł}$ & $86.38 \%$ \\
\hline Net loss & $4464802000 \mathrm{zł}$ & $11790981000 \mathrm{zł}$ & $264.09 \%$ \\
\hline Share of total costs in total revenues & $94.31 \%$ & $96.07 \%$ & $101.86 \%$ \\
\hline
\end{tabular}

Source: personal study based on Statistics Poland's data (Local Data Bank).

The worst situation appeared in processing industry enterprises, where the net financial results achieved in the first half of 2020 were lower by $39.03 \%$ compared to the same period of the previous year; net profits were lower by $13.62 \%$, but losses increased by $164.09 \%$. Revenues were at a level of $91.18 \%$ of those from the first half of 2019 , and the costs at $92.88 \%$. For this reason, the share of costs in revenues increased in the first half of 2020 to $96.07 \%$ from $94.30 \%$ in the comparative period of the previous year.

\section{CONCLUSIONS}

The SARS-CoV-2 coronavirus pandemic, as well as the restrictions introduced in connection with attempts to limit it, have drastically changed the conditions for the functioning of economic entities and consumer reactions. Enterprises have new threats, challenges and opportunities to development.

The results of Statistics Poland research in the first half of 2020 indicate that the emergence of the new Covid-19 illness, the speed and scale of its spread globally, implemented restrictions, and also possibly the media buzz related to it, has caused great uncertainty; and as a result, a sharp deterioration to entrepreneurs' moods in March and April 2020, as evidenced by drastic drops in the values of economic indicators. These moods improved in May and June 2020, despite the fact that the number of illnesses in Poland was gradually increasing at that time. It was likely caused by several factors, i.e. the passing of the initial shock, the gradual getting accustomed to new conditions of functioning, a relatively low percentage of illnesses (compared to other countries), the easing of restrictions, the launching of the Anti-Crisis Shield and financial support for enterprises, improving weather and the approaching holiday period. 
As of March 2020, over 90\% of surveyed business entities declared that they had experienced (to a lesser or greater extent) the negative impact of the COVID-19 pandemic on their business. However, taking actions to mitigate these negative effects (slightly or strongly affecting the activity) was indicated by over $70 \%$ of the surveyed enterprises. The largest percentage of entities which declared that they had not taken any special measures in this regard was recorded in the construction industry.

During the pandemic, the popularity of telework increased and a dependence on the need to maintain social distancing is quite evident - the greatest number of employees performed telework in March and April 2020, when restrictions in this regard were the highest. The experience of entrepreneurs shows that the most important advantages of this form of work include the reduction of the risk of contracting the coronavirus, and an increase in the flexibility of working hours. Yet, among the disadvantages are: lower efficiency, hardware problems, limitations in introducing new employees to duties, and difficulties in building social relationships and corporate culture (Kunica, 2020).

The shock caused by the pandemic was reflected not only in moods, but also in the financial results achieved by economic entities in the first half of 2020. As indicated by the results of the analysis, the largest decrease in net financial results was recorded by processing industry enterprises, as much as approximately $40 \%$ compared to the same period the previous year. Business entities providing services recorded a decrease in net financial results at a level of approximately $32 \%$, and those engaged in wholesale and retail trade at a level of approximately $12 \%$. However, companies conducting renovation and construction activities were in the most favorable situation; where net financial results for the period from January to June 2020, approximately $44 \%$ higher than for the same period of 2019, were recorded. Interestingly, such good financial results were not heralded by the mood in the construction industry, which were as pessimistic as in entities operating in manufacturing, trade or services, as evidenced by the monthly values of the general business climate indicator in the first half of 2020.

After the first half of 2020, the construction industry seems to be in the best situation, this may be due to the fact that it largely operates based on long-term contracts, and thus is less susceptible to temporary economic turmoil. The situation may change, however, as the uncertainty caused by the pandemic and the deterioration of the financial situation are not conducive to incurring capital expenditure, neither from public nor private funds.

The SARS-CoV-2 coronavirus pandemic is still ongoing. At the moment it is difficult to predict when it will end and what its further consequences will be; which will certainly be the subject of further scientific research.

The most important limitations of the analyses conducted in this article include:

- comparative analysis of companies' financial results in semi-annual instead of quarterly periods,

- generality of research on management actions taken by enterprises to counteract the negative effects caused by the SARS-CoV-2 coronavirus pandemic,

- incomplete consistency of the groups of enterprises included in the survey in terms of revenues, costs and financial results in 2019 and 2020, as well as groups of enterprises covered by the economic climate survey and the survey in terms of revenues, costs and financial results. 
These limitations result mainly from the adopted research methodologies conducted by Statistics Poland. The indicated limitations also create the possibility of conducting in-depth research in the future.

\section{REFERENCES}

Altig, D., Baker, S., Barrero, J.M., Bloom, N., Bunn, P., Chen, S., Davis, S.J., Leather, J., Meyer, B., Mihaylov, E., Mizen, P., Parker, N., Renault, T., Smietanka, P., Thwaites, G. (2020). Economic uncertainty before and during the COVID-19 pandemic. "Journal of Public Economics" 191 (2020) 104274.

Bartik, A.W., Bertrand, M., Cullen, Z.B., Glaeser, E.L., Luca, M., Stanton, Ch. (2020a). How are small businesses adjusting to covid-19? Early evidence from a survey. Working Paper 26989, "National Bureau of Economic Research". Access on the internet: http://www.nber.org/papers/w26989.

Bartik, A.W., Bertrand, M., Cullen, Z., Glaeser, E.L., Luca, M., Stanton, Ch. (2020). The impact of COVID-19 on small business outcomes and expectations. PNAS July 28, 2020117 (30). Access on the internet: https://www.pnas.org/content/117/30/17656.

Chiny: Najwcześniejszy zanotowany przypadek COVID-19 pochodzi z 17 listopada 2019, publikacja: 13.03.2020, „Rzeczpospolita”. Access on the internet: https://www.rp.pl/ Koronawirus-2019-nCoV/200319608-Chiny-Najwczesniejszy-zanotowany-przypadek-

COVID-19-pochodzi-z-17-listopada-2019.html

Craven, M., Liu, L., Mysore, M., Wilson, M. (2020). COVID-19: Implications for business. McKinsey \& Company.

Goodell, J.W. (2020). COVID-19 and finance: Agendas for future research. "Finance Research Letters" 35 (2020) 101512.

GUS (2018). Zeszyt metodologiczny. Badanie koniunktury gospodarczej. Warszawa: GUS.

GUS (2019). Zeszyt metodologiczny. Badania przedsiębiorstw niefinansowych. Warszawa: GUS.

GUS (2020a). Koniunktura w przetwórstwie przemysłowym, budownictwie, handlu i ustugach 2000-2020 (czerwiec 2020). Warszawa: GUS.

GUS (2020b). Koniunktura w przetwórstwie przemystowym, budownictwie, handlu i ustugach 2000-2020 (maj 2020). Warszawa: GUS.

GUS (2020c). Koniunktura w przetwórstwie przemystowym, budownictwie, handlu i ustugach 2000-2020 (kwiecień 2020). Warszawa: GUS.

GUS (2020d). Koniunktura w przetwórstwie przemystowym, budownictwie, handlu i ustugach 2000-2020 (marzec 2020). Warszawa: GUS.

GUS (2020e). Koniunktura w przetwórstwie przemysłowym, budownictwie, handlu i ustugach 2000-2020 (luty 2020). Warszawa: GUS.

GUS (2020f). Koniunktura w przetwórstwie przemystowym, budownictwie, handlu i ustugach 2000-2020 (styczeń 2020). Warszawa: GUS.

GUS (2020g). Koniunktura w przetwórstwie przemystowym, budownictwie, handlu i ustugachkwiecień 2020 r. Informacje sygnalne. Warszawa: GUS.

GUS (2020h). Wptyw pandemii koronawirusa SARS-CoV-2 na koniunkture gospodarcza-oceny $i$ oczekiwania (dane szczegótowe). Aneks do publikacji „Koniunktura w przetwórstwie przemystowym, budownictwie, handlu i ustugach 2000-2020 (kwiecien 2020). Warszawa: GUS. 
GUS (2020i). Wptyw pandemii koronawirusa SARS-CoV-2 na koniunkture gospodarcza-oceny $i$ oczekiwania (dane szczegółowe). Aneks do publikacji „Koniunktura w przetwórstwie przemystowym, budownictwie, handlu i ustugach 2000-2020 (maj 2020). Warszawa: GUS.

GUS (2020j). Wptyw pandemii koronawirusa SARS-CoV-2 na koniunkture gospodarcza-oceny $i$ oczekiwania (dane szczegótowe). Aneks do publikacji „Koniunktura w przetwórstwie przemystowym, budownictwie, handlu i ustugach 2000-2020 (czerwiec 2020). Warszawa: GUS. Heinonen, K., Strandvik, T. (2020). Reframing service innovation: COVID-19 as a catalyst for imposed service innovation. "Journal of Service Management Emerald Publishing Limited". Access on the internet: https://www.emerald.com/insight/content/doi/10.1108/JOSM-05-20200161/full/pdf?title=reframing-service-innovation-covid-19-as-a-catalyst-for-imposed-serviceinnovation https://pl.wikipedia.org/wiki/Pandemia_COVID-19_w_Polsce

Koronawirus. Najnowsze informacje z Polski i świata (RELACJA), publikacja: 30.06.2020 (2020). polsatnews.pl. Access on the internet: https://www.polsatnews.pl/wiadomosc/2020-0630/koronawirus-najnowsze-informacje-z-polski-i-swiata-relacja3006/

Kunica, M. (2020). "Powinniśmy przejść na model szwedzki". Prezes Comarchu podsumowuje pót roku lockdownu. Access on the internet: https://businessinsider.com.pl/firmy/janusz-filipiakprezes-comarchu-o-koronawirusie-i-pracy-zdalnej/fd2bv4h.

McKibbin, W., Fernando, R. (2020). The economic impact of COVID-19, [In:] Baldwin, R., Weder di Mauro, B. Economics in the Time of COVID-19. London: CEPR Press.

Nicola, M., Alsafi, Z., Sohrabi, C., Kerwan, A., Al-Jabir, A., Iosifidis, Ch., Agha, M., Agha, R. (2020). The socio-economic implications of the coronavirus pandemic (COVID-19): A review. "International Journal of Surgery" 78.

Oldekop, J.A., Horner, R., Hulme, D., Adhikari, R., Agarwal, B., Alford, M., Bakewell, O., Banks, N., Barrientos, S., Bastia, T., Bebbington, A.J., Das, U., Dimova, R., Duncombe, R., Enns, Ch., Fielding, D., Foster, Ch., Foster, T., Frederiksen, T., Gao, P., Gillespie, T., Heeks, R., Hickey, S., Hess, M., Jepson, N., Karamchedu, A., Kothari, U., Krishnan, A., Lavers, T., Mamman, A., Mitlin, D., Tabrizi, N.M., Müller, T.R., Nadvi, K., Pasquali, G., Pritchard, R., Pruce, K., Rees, Ch., Renken, J., Savoia, A., Schindler, S., Surmeier, A., Tampubolon, G., Tyce, M., Unnikrishnan, V., Zhang, Y.-F. (2020). COVID-19 and the case for global development. "World Development" 134.

Wyplosz Ch. (2020). The good thing about coronavirus [In:] Baldwin, R., Weder di Mauro, B. Economics in the Time of COVID-19. London: CEPR Press.

DOI: $10.7862 /$ rz.2020.hss.45

The text was submitted to the editorial office: September 2020. The text was accepted for publication: December 2020. 